\title{
International press and diplomatic circumstances in Kosovo in the years 1988-1990
}

\author{
Dr.Sc. Isak Sherifi \\ Albanian /Macedonia \\ i.sherifi@hotmail.com
}

DOI:10.5901/mjss.2014.v5n19p274

\begin{abstract}
The dramatic events of 1988 and 1989 years in Kosovo, followed by strikes, protests and demonstrations in defense of the autonomy of Kosovo began with "Trepca" miner's incarceration in seven-day strikes in the depths of the mine galleries. Students and Kosovo people continued strikes, affected agencies and the strongest international newspaper journalists to come in Kosovo and inform their readers what actually was happening in Kosovo. Events in Kosovo undertaken by internal affairs organs of the Yugoslav Federation caused numerous reactions in domestic opinion as well as in the international. CNN, $B B C$, France Press, DPA, Corriere della Sera, ANSA and many other mediums were giving a completely true situation in front of other official state propaganda then. These media correspondents were reporting on the continuing violence arrests and killings of Kosovo citizens by these state bodies. These were brave journalists who disseminated in public the appearance of intellectuals isolated in Kosovo that were being held in prisons without the right decision and the question of: What would happen to them if they do not come on the front pages of news in these media? As a merit of their work, Kosovo came on the front pages of all prestigious international journals which set in motion the intellectual elite of their countries and official reactions to the states. Thanks to these reports Kosovo for the first time was visited by a European Parliament delegation who was informed closely with the real situation.
\end{abstract}

Key words: mediums, newspaper, journalists, news, delegation.

\section{Introduction}

Yugoslav Federation has never been more disorganized than in the period of 80-90 years. All Yugoslavia eagerly was waiting for federal government actions and the head of state reaction that were very silent about new events in Kosovo while in the other side foreign media tools will assess. The pressure that was consistently done to the Albanian people and its autonomy, enshrined in the 1974 constitution by Serbia will push the Assembly delegates to state clearly to the positions that had begun to apply Serbia on Kosovo.

Convinced that only independence and self-determination could save Albanians from the cataclysm that threatened them, delegates on the assembly held on 2 July 1990 will declare the independence. After this act, internal affairs bodies of the Yugoslav Federation would be forced to take actions which will cause many reactions in the internal and external opinion. Manifestations of peace and political autonomy precede more serious event for the Albanian people. Serbia made final preparations for the final destruction of Kosovo's autonomy after the open support given to Serbian hegemony from other republics in the embarrassing way that the ruling party had begun. Major campaign to change the constitution of Kosovo with which would definitely deal the autonomy takes its epilogue. Serbia on 23 March 1989 put Kosovo on a military curfew. Conversely Albanian people will start organization and its epicentre will be Trepca miners. Miners earlier investigated what is expected and what was prepared for Albanians and what the government had prepared at that time. In this constant pressure that was done to them and the people in general they decided to lock themselves in the mine galleries to sacrifice themselves to draw the attention of world public opinion against the demolition of autonomy that their government was doing. Trepca miners will join the other miners throughout Kosovo. One of the main demands of the miners was giving strong guarantees that three Kosovar leaders Shukriu Ali, Rahman Morina and Hysamedin Azemi who escorted demolition of autonomy will resign irrevocably, and without strong guarantees received by the leaders of the Kosovo Yugoslav constitution will not be changed against the will of people. At this time hundreds of people were abused and imprisoned and in police hands crossed over 500 thousand. Trepca miners act actually will draw worldwide attention mostly in Kosovo that followed with a general strike. 


\section{Political developments in Kosovo-1988-1989 \\ Protests -Miners strikes}

Dramatically events of years 1988 and 1999 in Kosovo followed by strikes, protests and demonstrations to defend the Kosovo autonomy which starts with isolations of miners of mine "Trepca" in seven days strikes in deep mine galleries and continued strikes of students and nation of Kosovo effected that in Kosovo come journalist of agencies and the most powerful international newspapers to reflect the situation and to inform the situation much more real to their readers of what was happening in Kosovo.

Events in Kosovo undertaken by the Interior Yugoslav Federation body caused many reactions as in internal opinion also in international opinion too. CNN, BBC, France Press, DPA, Corriere della serra, ANSA and many other media were showing completely different situation in rapport with official propaganda of state. The correspondents of this media were reporting about the ongoing violence, arrests and also for killing of people in Kosovo from the state agencies. Were exactly these brave journalists who disseminated in opinion the occurrence of isolation of the intellectuals of Kosovo who were kept on prisons without any judgment and with no right for question: what will happen to them if the news will not invade the first pages of this media?

As a merit of their job, Kosovo was in the first pages of the international prestigious newspapers that moved the elite intellectuals of their places and brought the official reactions of their states. Owing to these reports for the first time Kosovo was visited by European Parliament delegation, which was persuaded closely with the real situation.

\section{Positive reactions of world relevant institutions}

On October of year 1990 in Kosovo stayed a delegation with four members of the committee for the international humans rights of lowers association chamber of New York (U.S.A).The delegation headed by Warren P Stern in constitution by Michael E Galigan, Deborah J. Jacobs and Morris J. Panner met Yugoslav and Serbs official of that time also with a specialized lowers for the human rights and with Albanians who were the victims of human rights violation.

Final product of this mission was the huge report of 80 (eighty) pages "Kosovo crisis and human rights in Yugoslavia" which was distributed to the international opinion on 13 (thirteen) February 1990. From this report in some pieces where it's given the history of Kosovo from the time of Roman empire till the creation of Yugoslavia, the status of Kosovo within Yugoslavia the beginning of crisis and the actual situation continually give in integral way the part which has to do specifically and directly with violation of human rights in Kosovo.

Die Press newspaper said that the Serbian government and the opposition are unique in the current action and they are competing with regard to the severity of the Kosovo Albanians. (Rilindja $1990 \mathrm{pg} .2$ )

After the new situation created in Kosovo with the suspension of the Kosovo Assembly from Serbia FKADNJ (U.S. Congressional Foundation for Human Rights) made this appeal to the George Bush administration about recent actions by the Serb government, who enhanced the confrontation between ethnic Albanians in Kosovo province of Yugoslavia and Serb forces that were controlling the region. The members of congress foundation for the human rights they appeal to Bush administration to express the big troubles that the hostile acts which are taken by Serbian government may taken to destroy the Yugoslavia.

Congressional members of the Foundation for Human Rights make appeal to the Bush administration and express concern that hostile acts undertaken by the Serbian government could lead to the destruction of Yugoslavia. Congress members make call for reconsideration of U.S. policy toward Yugoslavia by introducing the criterion of human rights in determining U.S. policy. (Rilindja.1990 pg.4) Members of Congress will also express their concern that the Yugoslavia waywardness would destabilize the Balkans region and will lead to ethnic conflicts.

Monita-an Italian newspaper of Rome says that: the response of federal leadership will not be expected much but the room for negotiation is excessively narrow. (Rilindja 1990 pg.3) Sofia Duma says that Yugoslav republics with large fever are acting about the major changes to their state sovereignty and are committed to expect much more the inevitable concern in case of profusion of the federation. Paris AFP thinks that united Albanian opposition has decided to respond with passive resistance in case of profusion of the federation. On the other hand IRNA of Tehran says that the Albanian population of 
Kosovo has decided to offer guardian resistance, while Serbia will react more quickly to calls for strikes and warned that it will not tolerate interruption of production in the province. (Rilindja 1990 pg.4)

\section{Positive evolutions of the international mechanism}

At the Conference on the Human Dimension of the CSCE in Copenhagen in June 1990, the U.S. delegation chief, Max Kampelman said that " the violence is worrying in Yugoslavia", and advised the Yugoslavian government that Kosovo problems will not be solved without dialogue with Albanian democratic organizations.

U.S. Department on June 30, after expressing the grave concern about the created situation and tensions in Kosovo finds that the choice cannot be done with threats. U.S. Senator, Larry Pressler after hearing for declaring Kosovo an independent and democratic subject wrote a letter to U.S. Secretary of State James Baker and urged the U.S. government to find a way to provide support of independence act and strong democratic movement in Kosovo, and the possibility for self determination of Kosovo citizens. The first resolution that came before the House of Representatives is the U.S. Congress's resolution of November 1990, sponsored by Senator Alfonso D'Amato and Congressman Larry Pressler. This resolution in one manner "interrupts the continuity" of "thirteen resolutions before" (1986-1991), regarding the recognition of further SFRY.

Presler D'Amato-resolution raises new approach to the space of the former Yugoslavia. (Blerim Reka, Pristina 1995)

In the Resolution for Kosovo in five points are specified congressional conclusions about the situation in Kosovo.

First, it expressed gratitude to the Albanians for patience in this difficult period and also hailed their determination for solving problems peacefully and democratically.

Secondly it is required by the SR government of Serbia to join the peaceful and democratic dialogue with representatives of the Albanian community in Kosovo, including the LDK. The Belgrade government is invited to stop violence, intimidation, threats and use of force. (Glareva Fitim, 2004)

Third it is stated in the Resolution that "the president of Serbia (Milosevic) should abandon his disastrous policies. In resolution Milosevic is openly blamed for "ruining the conditions for peaceful and democratic elections in Kosovo, which will respect the rights of all citizens".

Fourth "Yugoslav and Serbian government is invited to provide full autonomous status for the province of Kosovo and to restore the legitimacy of the government in Kosovo".

Fifth "The U.S. head required from the highest level of the Yugoslav government of Congress to express concern because of the situation in the province." (Dielli-1992 p.2)

In 1992, to the House Representatives of the U.S. Congress appeared only a separate draft resolution on Kosovo, it was 21 resolution sponsored by Congressman Tom Lantos. The requirement of this resolution was "Recognition of the Republic of Kosovo by the U.S. President". (Blerim Reka, Pristina 1995) The demand for "recognition of the Republic of Kosovo" was justified by the fact that Kosovo is defined as sovereign in the first National Liberation Conference, held on January 1 , 1944, and the Constitutions of the SFRY in 1946 and 1974, as one of the constituents of the Yugoslav federation. Serbia destroyed the autonomy on March 23, 1989 without the consent of the people of Kosovo and the Kosovo Assembly on 2 July 1990 proclaimed Republic of Kosovo it has approved the Constitution of the Republic of Kosovo on 7 September 1990 based on the principle of self-determination, equality and sovereignty. This resolution sought to guarantee the rights and freedoms according to international standards, and relied on the principle that all peoples are entitled to completely free to decide their internal and external political status. (Blerim Reka, Pristina 1995)

\section{Concretization of international pressure on Serbian hegemony}

On May 27, 1990 in Pristina a group of U.S. Congressmen Tom Lantos, Joseph Dio Guardi met with Ibrahim Rugova and other members of the party, the crowds were waiting, but even here the police violently dispersed them. In an interview given to the daily "Rilindja", U.S. Congressman Tom Lantos said "We will take care for Kosovo till the end ". (Ndreca Mikel, 2001) The visit of U.S. Congressmen from Belgrade was considered as a violation of sovereignty of Yugoslavia and Serbia. Another visit of U.S. senators who will point out the bloody purpose of Belgrade and the Milosevic regime will be the visit of Senator Robert Dole. 
Senator was expected from a large crowd of people who found a kind of support from Americans, but this crowd was mistreated by Serbian police. In this case many participants were seriously injured and later they were imprisoned many of them with quick trial proceedings. Senators advised and warned the Albanian leaders to be more careful and to avoid Serb provocations.

The European Parliament in Strasbourg on 13 July 1990 adopted a resolution which condemns dissolution of the Assembly of Kosovo, Serbian government control over the media in Albanian and demanded immediate suspension of extraordinary measures in Kosovo.

European Parliamentarians urged that the1974 constitution should be respected, while the House of Representatives of the U.S. Congress approves a resolution on Kosovo and asked the Government of Kosovo to stop the violence, intimidation and use of force and to resolve political and economic crisis in province. In the content of the resolution was required:

\section{Release of political prisoners since 1981}

2. Decides to send in Kosovo the delegation and requests from the Yugoslav authorities to ensure free circulation,

3. Authorizes its president to forward this resolution to Commission, Council of Ministers the European Parliament also to the Serbian and Yugoslav governments.

\section{Requires recognition of the legitimacy of parliament scattered from Serbia}

5. Resumption of work for prohibited newspapers and Pristina Television this respecting the freedom of expression and the press, having accounted the eviction from Kosovo on 3 September 1990 of the members from the international federation for the human rights by Serbian authority. Interruption of killing, torture, arbitrary detention harassment of the Albanian political prisoners avoid the censure and back on duty all Albanian's who were suspended from march of year 1989. Requires form Serbian authority, to withdrawal the army and police forces from Kosovo.

\section{Euro-Western press about the events in the former Yugoslavia - Kosovo}

Violent measures that were taken from the bodies of internal affairs of the Yugoslav Federation in Kosovo caused numerous reactions in domestic opinion as well as in the international. Various press agencies like BBC World, Frans Press Agency, DPA Agency, courier Della Sera, Frankfurter rundeshau, Allgemajne Frankfurter Zeitung and many others reacted immediately.

Most of the media will try to touch in the core of the problems that Kosovo was facing. Some of Austria's newspapers will bring information about new measures in Kosovo they will ascertain the removal of Kosovo's autonomy. The newspaper "Standard" means that "witnesses have reported that in Kosovo, Serbia has sent tanks and further added that a day before the Serbian Parliament approved emergency procedure law that the Albanian government in Kosovo is denied and replaced with Serbian representatives "(Rilindja 1990 p.3) This newspaper also publishes commentary titled "Serbia greets" stating that taking full power shows that Serbs in Kosovo have already agreed with the distribution of the Yugoslav Federation.

While the newspaper "Folkshtime" writes that the Serbian Parliament has decided to abolish the autonomous rights of Kosovo, because this region is occupied by the Belgrade military and police emergency situation over there.

BBC also says that under the new constitution that is being prepared in Serbia, the Kosovo Assembly will lose most of its current powers, all legislative power will pass in Serbian assembly. The Boston Globe about the situation in Kosovo in an article entitled "Kosovo democracy" among others will write that Kosovo is under the control of the Serbian police force which is used to extinguish the protests and that "in this province where Albanians make up 90 percent of the population, the state of emergency was implemented over a year ago " (Rilindja,1990, p.3). Chicago Tribune in an article entitled "The Last sickness of Yugoslavia will highlight that between stormy changes in Eastern Europe," Yugoslavia looks like a corpse that refuses to rot "(Rilindja, 1990, p.3). Without Slovenia, or perhaps even without the southern province of Kosovo, where Serbs still demonstrate their iron muscles, perhaps Yugoslavia could continue somehow, but her life would not last a minute with the emergence of Croatia. More than in any European country living together in Yugoslavia was imposed more strongly than with the consent of its people it did it to call a "seasonal state." In an article entitled how to control Kosovo from Frans Press Agency in its report assesses that Serbia has given serious punch to the province of Kosovo, which has enjoyed broad autonomy and that actually was the seventh Republic of Yugoslavia and here is seen the Albanian opposition clearly expressing the nervousness which adversely await the decision of Serbia. DPA Agency notes that Serbia has taken the final step in conflict with the Albanians of Kosovo and that this Serbian decision represents a reaction to declaration of Kosovo republic. However, it is uncertain how Serbia will check the province in her daily life and will give the apparent 
resistance of Kosovo Albanians. The Vienna "Presse" in a comment titled "The relative triumph" states that with the distribution of the assembly were disappointed aspirations of the people of Kosovo to independence.

Milan Journal "Corriere Della Serra" will clarify the decisions taken in the Federal Republic which differed from the Republic in Republic. In Serbia the decisions were taken as a victory, while in Croatia, Slovenia and Kosovo these decisions dealt with indignation. Rome newsletter called "Republic" will consider that the decision of Belgrade will contribute to an increase of the tensions while Slovenian and Croatian forces will use that in distribution of the Yugoslav Federation. (Bujku. 1990 p.9).

Washington Times estimates that increased tension and transnational political rejection even more will bring the perspective of a definitive distribution as the most unstable country in the Balkans "(Bujku. 1990 p.9). Rundschau Frankfurter wrote that if the disintegration of Yugoslavia happens, one of the biggest problems will be setting the borders between the present republics.

BBC will report that the Kosovo issue to the world will remain internal affair of Yugoslavia until it would endanger peace in the Balkans, which can easily happen. "Gjopn" wrote that in Slovenia is considered that the current measures taken in Kosovo because the political beliefs of the Provincial Assembly delegates are distributed unacceptable to Serbian officials. "(Mladina, 1990 p.24)

UPI about the situation in Kosovo will outline that Serbian government bodies will intend to bring to trial the perpetrators of the declaration of independence of Kosovo from Serbia. (Mladina, 1990 p.24)

The foreign press as Paris RFI (radio) will also mention two events that took place in 90th-to the declaration of autonomy of Serbs in Croatia in a mass rally and the second event was the announcement of the victims number who suffered in Kosovo and was presented as 28 from the Federal Parliament, while in reality this number was 90.

If this news will be exact and number 90 who suffered would be correct (and that was actually correct) then there is no reason that this event the journalistic standard language should call a massacre". (Rilindja 1990 p.3) In further explanation of this supposed event that Serbian police seems poorly led and that its members have done what they wanted or that the word is preparing a genocide against the Albanian population, against which they can do whatever they want or the word is for preparing provocations against the Albanian population with only an armed uprising would be a pretext for repression with wide dimensions will conclude RFI. (Rilindja 1990 p.4) Italian news agency "ANSA" informs that "Kosovo Albanians were massacred and thousands of young people have been killed, tortured and arrested". (Jakup Krasniqi, 2006 p.222)

German newspaper "Frankfurter Allgemeine Zeitung " in the article "Today Kosovo and then" wrote: "Most of the Albanian deputies in the Assembly of the Province were forced to vote for constitutional amendments. But it seems strange that as the Yugoslav Federation sees with cross-handed the repressive policy of Serbia. Apparently some republican leadership thought that: while Milosevic is busy with the occupation of Kosovo, their Republic will be in peace. This could be miscalculation. "(Jakup Krasniqi, 2006 p.223)

The newspaper "Vjesnik" wrote: "political game about Kosovo and empty promises that will be implemented immediately after taking power is experiencing its peak the paper concludes. In all this "chauvinistic program of Albanian leaders and its creators took place again, against the militia led out by children and mothers, they directed volley and stones against the Serbian and Montenegrin houses"

\section{Short Reflection}

The period of the years 1988 - 1990, respectively political events in Kosovo that went through that period and wider in ex Yugoslavia, are reflected everywhere in the world mass media of the time. It remains important that most of them have reported objectively and with foresight putting under lentil the risk of the pressure coming from the collapse of the rights of Kosovo Albanians, and not only Kosovo Albanians, but also beyond. The years following, as the politics will develop would entitle all mass media and international institutions that went specifically against hegemonic and wild regime time, forcibly installed in the dome in undemocratic political way and military of the former Yugoslavia - unequivocally after the destruction of Yugoslavia-Serbia.

The role of print and electronic media is one of the most reflective powers for developments in subsequent and former Yugoslavia and Kosovo. If politicians knew that they read messages of sincere lovers across multiple mass media peace institutes and other institutions of Kosovo the world today would talk about different successes, not only in Kosovo, but in all ex - Yugoslavia. 


\section{References}

Academy of Sciences and Arts; "Kosovo an independent and sovereign state", Prishtina, 2006; Academy of Sciences and Arts; "The future status of Kosovo", Prishtina 2005 ; Academy of Sciences of Albania RPS "The truth about Kosovo and Albanians in Yugoslavia" Tirana 1990; Academy of Sciences (Encyclopedia center Albanian) Kosovo in the face encyclopedic; Toena; Tirana 1999 ; Alush Kamberi big Prosecutions, Skopje, 1999 ; Eid Education; "The right of Kosovo in transition" Prishtina 2002 ; Berisha Bekir; "The Albanian national question and" Albanian ultrakomunistët ", Tetovo 1996 ; Rame Buja; "The Rambouillet Conference (legal aspects, political and international), Pristina 2004 ; "Expulsions of Kosovo Albanians and colonization (1877-1995)" Prishtina 1997 ; Eva Hyskaj Tafili-political transition in Central and Eastern Europe, Tirana 2008 ; Joschka Fischer Red-Green Years, Time, Pristina; 2008 ; Gleny Misha; "Balkan History1804-1999; Grenades books, London 2000 ; Gllareva Fitim "American Diplomacy 1989-1999 conflict in Kosovo" Pristina 2004 ; Gruda Zejnullah; "International protection of human rights" Prishtina 2000; J. Henry H. Perritt; "Kosovo Liberation Army-Confession within a mutiny ", Prishtina 2008 ; Enver Hasani; "The disintegration of Yugoslavia and Kosovo" Pristina 2000 ; Institute of Contemporary History "Kosovo an independent and sovereign" - Prishtina, 2006 ; Tim Judah; "Kosovo war and revenge" Prishtina 2002 ; Kiçmari Sabri: "Kosovo as an independent sovereign state" Pristina, 2006; Kraja Mehmet; "Years lost" Tirana 1995 ; Jakup Krasniqi; "Big turnaround" Prishtina 2006; Ndreca Mikel; "87 years of state terror and genocide (1912-1999), Pristina, 2001; Wolfgang Petrich \& Robert Pihleri; "The long road to war" Prishtina 2002; Blerim Reka: "Kosovo in U.S. Congress documents (1986-1995) Pristina 1995 ; Jens Reuter; "Albanians in Yugoslavia" Tirana 2003; Sulo Arifay "KLA between support and obstacles" Prishtina 2000 ; Shala Xhavit, "The Balkans, geopolitics and security", Tirana 2009 ; Blerim Shala; "Kosovo Years 1998-1999 " Pristina 2000 ;Edita Tahiri; "The Rambouillet Conference (negotiation process and documents)", Peja 2001; Press; Newspaper "Renaissance", 1989, 1990 (p.2,3,4);; The magazine "Time", Pristina, December, 1990; Newspaper "Flame of brotherhood", 1991; Newspaper "authentic democracy" February 1991; Newspaper "Our Way" Lyon France 1997; Exclusive Magazine "Dossier K" Pristina January 2001 ; Magazine "Diplomacy" March 2003; Daily -feuilleton-April 2005; Newspaper "Time" March 27, 2007; Daily newspapers, 'Time "; 2008; Journal News 24 February 2012; http / rks.gov.net / MFA 